九州大学学術情報リポジトリ

Kyushu University Institutional Repository

\title{
The Roles of Angiotensin II in Stretched Periodontal Ligament Cells
}

\section{Monnouchi, Satoshi}

Division of Oral Rehabilitation, Department of Endodontology and Operative Dentistry, Faculty of Dental Science, Kyushu University

Maeda, Hidefumi

Department of Endodontology, Kyushu University Hospital

Fujii, Shinsuke

Tomokiyo, Atsushi

Division of Oral Rehabilitation, Department of Endodontology and Operative Dentistry, Faculty of Dental Science, Kyushu University

他

http://hdl. handle. net/2324/25451

出版情報: Journal of Dental Research. 90 (2), pp.181-185, 2011-02. International \& American Associations for Dental Research

バージョン :

権利関係: (C) 2012 by International \& American Associations for Dental Research 


\section{The roles of angiotensin II in stretched periodontal}

\section{ligament cells}

S. Monnouchi ${ }^{1}$, H. Maeda ${ }^{2 *}$, S. Fujii ${ }^{2}$, A. Tomokiyo ${ }^{2}$, K. Hori $^{1}$, and A. Akamine $^{1,2}$

${ }^{1}$ Division of Oral Rehabilitation, Department of Endodontology and Operative Dentistry, Faculty of Dental Science, Kyushu University, and ${ }^{2}$ Department of Endodontology, Kyushu University Hospital, 3-1-1 Maidashi, Higashi-ku, Fukuoka 812-8582, Japan; *corresponding author, hide@dent.kyushu-u.ac.jp

$<$ Information >

1) short title; Ang II mediates the signal in stretched PDL.

2) three key words ; HPLF, stretch, angiotensin II

3 ) the number of words in the abstract ; 146 words

4) the number of words in the abstract and text ; 2499 words

5) the number of tables and figures ; 4 figures

6 ) the number of cited references ; 28 references 


\section{ABSTRACT}

The loading caused by occlusion and mastication plays an important role in maintaining periodontal ligament (PDL) tissues. We hypothesized that a loading magnitude would be involved in the production of biological factors that function in the maintenance of PDL tissues. Here, we identified up-regulated gene expressions of transforming growth factor- $\beta 1$ (TGF- $\beta 1$ ), alkaline phosphatase (ALP) and angiotensinogen (AGT) in human PDL fibroblastic cells (HPLF) that were exposed to $8 \%$ stretch loading. Immuno-localization of angiotensin I/II (Ang $\mathrm{I} / \mathrm{II})$, which were converted from AGT, were detected in rat PDL tissues. HPLFs that were stimulated by Ang II also increased their gene expressions of TGF- $\beta 1$ and ALP. Furthermore, the antagonist for Ang II type 2 receptor, rather than for type 1 , significantly inhibited gene expressions induced by the stretch loading. These data suggest that Ang II mediates the loading signal in stretched HPLFs to induce expressions of TGF- $\beta 1$ and ALP. 


\section{INTRODUCTION}

Periodontal ligament (PDL) is a dense specialized connective tissue that lies between the cementum and the alveolar bone. The homeostasis of PDL tissues is maintained while continuously being subjected to the mechanical tensile loading caused by occlusion and mastication (Yamaguchi et al., 2002). Human PDL cells are known to include osteoblastic properties and to express alkaline phosphatase (ALP) (Somerman et al., 1988). It has been reported that, while the basal ALP activity in human PDL cells tends to increase, the cells also can differentiate into osteoblastic cells and form mineral-like nodules, depending on various extracellular stimuli (Basdra and Komposch, 1997). On the other hand, human PDL cells are also known to express receptor activator of nuclear factor kappa B ligand (RANKL) (Wada et al., 2004), a known regulator of osteoclastogenesis (Udagawa, 2002). RANKL signaling is inhibited by osteoprotegerin (OPG), and one of the biological roles of OPG in the PDL may be the protection of the tooth from attack by osteoclasts activated by various stimuli (Wada et al., 2001).

Mechanical stress is an essential stimulus for the development, function and repair of the major elements of the musculoskeletal system, such as bones, 
tendons, ligaments and cartilage. Among these stress, stretching loading is known to be one of the important regulators of ligament and tendon remodeling (Kim et al., 2002). It has been reported that proper mechanical stimulation is required for maintaining PDL tissues (Shi et al., 2005).

The renin-angiotensin system (RAS) has been described as a major regulator of cardiovascular physiology and has been strongly implicated in the development of several cardiovascular diseases including hypertension and cardiac hypertrophy (Senbonmatsu et al., 2003). Angiotensin II (Ang II), a vasoactive octapeptide, is converted from angiotensinogen (AGT) via angiotensin I (Ang I) (Jeunemaitre et al., 1992) and plays an important role as the principal mediator of RAS (Tamura et al., 1998). It has also been reported that Ang II contributes to stretch-induced hypertrophic responses (Yamazaki et al., 1995). In mammals, Ang II acts via the Ang II type 1 receptor (AT1) and type 2 receptor (AT2). AT1 and AT2 exhibit limited sequence homology ( $34 \%$ amino acid sequence identity) (Inagami et al., 1992). In bone tissue, AT2 is expressed in both osteoblasts and osteoclasts in vivo, and the treatment with AT2 blocker has increased bone mass through both enhancement of osteoblastic activity and suppression of osteoclastic activity in vivo (Izu et al., 2008). 
In the present study, we report the response of human PDL fibroblastic cells

(HPLF) exposed to stretch loading and the correlating role of Ang II in the signaling of these cells. 


\section{MATERIALS \& METHODS}

\section{Reagents}

Recombinant human Ang II was purchased from Calbiochem

(Darmstadt, Germany). Signaling pathways were investigated using specific antagonists: candesartan (10 ng/mL, TRC Inc., NY), an antagonist of AT1, and PD123319 (100 nM, Sigma, St Louis, MO), an antagonist of AT2.

\section{Cell Culture}

HPLFs were obtained from healthy third molars that were extracted for orthodontic reasons and prepared as previously described (Fujii et al., 2006).

Cells isolated from a 30-year-old female and a 39-year-old female were denoted as HPLF-2D and HPLF-2E, respectively. All cells were cultured in alpha-minimum essential medium (a-MEM, Gibco-BRL, Grand Island, NY), supplemented with $50 \mu \mathrm{g} / \mathrm{mL}$ streptomycin and $50 \mathrm{U} / \mathrm{mL}$ penicillin (Gibco-BRL) and containing $10 \%$ fetal bovine serum (FBS, Gibco-BRL; $10 \%$ FBS/a-MEM), at $37^{\circ} \mathrm{C}$ in a $5 \% \mathrm{CO}_{2}$ incubator. HPLFs underwent 5 to 6 passages prior to use in the experiments. All the procedures in this study were performed in compliance with the regulations of Kyushu University. 


\section{Application of Mechanical Stress}

Stretch loading was applied to HPLF cultures using STB-140 (STREX, Osaka, Japan) in a $\mathrm{CO}_{2}$ incubator. HPLFs were pre-cultured in flexible-bottomed culture chambers coated with type I collagen (Cell matrix I-P, Nitta Gelatin Inc., Osaka, Japan) until reaching sub-confluence. HPLFs were subjected to stretch loading ( 0,8 and $12 \%$ elongation, $0.5 \mathrm{sec}$ stretch and $0.5 \mathrm{sec}$ relaxation per cycle) for 1 h. After loading, HPLFs were subjected to RNA extraction.

\section{Semi-quantitative RT-PCR}

Total RNA was extracted using TRIzol Reagent (Invitrogen, Carlsbad, CA) according to the manufacturer's instructions. First-strand cDNA synthesis and PCR were performed using a Thermal Cycler Dice (Takara Bio Inc., Shiga, Japan) as described previously (Maeda et al., 2005; Tomokiyo et al., 2008). Each cycle consisted of a heat denaturation at $94^{\circ} \mathrm{C}$ for $30 \mathrm{sec}$, annealing for 30 sec and extension at $72^{\circ} \mathrm{C}$ for $30 \mathrm{sec}$. Annealing temperatures were optimized for each primer-pair as follows: GAPDH [452bp]: sense, 5'-ACCACAGTCCATGCCATCCAC-3', antisense, 
5'-TCCACCACCCTGTTGCTGTA-3' , 60C; RANKL [196bp]: sense, 5'-ACCAGCATCAAAATCCCAAG-3', antisense, 5'-CCCCAAAGTATGTTGCATCC-3', 59 ${ }^{\circ} \mathrm{C}$; OPG [472bp]: sense, 5'-GTACGTCAAGCAGGAGTGCAATC-3', antisense, 5'-TTCTTGTGAGCTGTGTTGCCG-3', 55 C. GAPDH primers were used as internal controls. The PCR products were analyzed using picture-imaging software (NIH Image; National Institutes of Health, Bethesda, MD).

\section{Quantitative RT-PCR}

First-strand cDNA was synthesized from $1 \mu \mathrm{g}$ of total RNA using ExScript RT Reagent kit (Takara Bio Inc.). Briefly, total RNA was reverse-transcribed with random 6 mers and ExScript RTase for $15 \mathrm{~min}$ at $42^{\circ} \mathrm{C}$, and the reaction was stopped by incubation for $2 \min$ at $99^{\circ} \mathrm{C}$, followed by $5 \min$ at $5^{\circ} \mathrm{C}$. PCR was performed using SYBR Green I (Takara Bio Inc.) in a Thermal Cycler Dice Real Time System (Takara Bio Inc.) under the following conditions: $95^{\circ} \mathrm{C}$ for $10 \mathrm{sec}$ (initial denaturation), followed by 40 cycles of $95^{\circ} \mathrm{C}$ for $5 \mathrm{sec}$ and $60^{\circ} \mathrm{C}$ for $30 \mathrm{sec}$, followed by a dissociation program at $95^{\circ} \mathrm{C}$ for $15 \mathrm{sec}, 60^{\circ} \mathrm{C}$ for $30 \mathrm{sec}$ and $95^{\circ} \mathrm{C}$ for $15 \mathrm{sec}$. A human $\beta$-actin primer was used as an internal control. Expressions 
of the target genes were calculated from the delta-delta Ct values. Specific

primer sequences for each gene purchased from Takara were as follows: $\beta$-actin [89bp] : sense, 5'-ATTGCCGACAGGATGCAGA-3', antisense

5'-GAGTACTTGCGCTCAGGAGGA-3'; transforming growth factor- $\beta 1$ (TGF- $\beta 1$ )

[125bp]: sense, 5'-AGCGACTCGCCAGAGTGGTTA -3', antisense, 5'-AGTACATGGCGTAACCTCTAGTCA-3'; ALP [118bp]: sense, 5'-GGACCATTCCCACGTCTTCAC-3', antisense, 5'-CCTTGTAGCCAGGCCCATTG-3'; AGT [182bp]: sense, 5'-AGCTGCCGTTGTTCTGGGTACTA-3', antisense, 5'-GTGGAGCAGTAGGTGTTACTCTCA-3'; RANKL [174bp]: sense, 5'-TGGATGCCTTGAATAATAAGCAGGA-3', antisense, 5'-AAGGTGTTCACGGCGTTTAA-3'; OPG [196bp]: sense, 5'-TGGCACCAAAGTAAACGCAGAG -3', antisense, 5'-CTGTACGATTGGAGTGGAAGCTC-3'.

\section{Detection of Ang II in vivo and in vitro}

All procedures were approved by the Animal Research Committee of Kyushu University. 
Five-week-old Sprague-Dawley rats were purchased from Kyudo Co. Ltd. (Saga, Japan) and were perfused through the left ventricle with $4 \%$ paraformaldehyde (PFA). The mandibles were dissected, decalcified in $10 \%$ EDTA solution and embedded in paraffin. Five $\mu \mathrm{m}$ horizontal sections of the first molars were prepared. Immunohistochemical analysis was performed using an anti-Ang I/II antibody (Santa Cruz, CA, USA) as a primary antibody and a biotinylated anti-goat IgG (Nichirei Biosciences Inc., Tokyo, Japan) as a secondary antibody. Positive reactions were visualized with Simple Stain DAB Solution (Nichirei). HPLFs were fixed with 4\%PFA and $0.5 \%$ dimethyl sulfoxide (Wako, Osaka, Japan), and the expressions of Ang I/II were also examined immunocytochemically with the same procedure.

\section{Statistical Analysis}

All values are expressed as mean $\pm \mathrm{SD}$. Statistical analysis of the results was performed using the Student's paired t-test. 


\section{RESULTS}

\section{Subjection of HPLFs to stretch loading}

Gene expressions of RANKL and OPG were examined from HPLF-2E cultures

exposed to stretch loading at a frequency of $60 \mathrm{cycles} / \mathrm{min}$ with 0,8 or $12 \%$

elongation. After $1 \mathrm{~h}$, the expression level of RANKL mRNA was significantly

down-regulated by exposure to $8 \%$ stretch loading as compared with

non-loading, whereas the expression was up-regulated by exposure to $12 \%$

stretch loading $(P<0.02)(F i g .1 A)$. The expression level of OPG mRNA was

up-regulated by exposure to both $8 \%$ and $12 \%$ stretch loading as compared with

non-loading $(\mathrm{P}<0.02)($ Fig. 1B). Because these data suggested that $8 \%$

elongation may exert inhibitory effects on osteoclastogenesis in HPLFs, we used

this magnitude in subsequent experiments. Next, we examined the effects of $8 \%$

stretch loading on gene expression in HPLF-2D and -2E cultures by quantitative

RT-PCR. The expression levels of TGF- $\beta 1$ and ALP mRNA were up-regulated

by exposure to stretch loading as compared with non-loading (Figs. 1C, 1D).

Interestingly, stretch loading also up-regulated AGT mRNA expression in both

HPLF cultures (Figs. 1C, 1D). 


\section{Localization of Ang I/II in rat PDL tissues}

The expression of Ang I/II was examined using rat PDL tissues and HPLF-2E

cultures. In rat periodontal tissues, the intense immunoreactivity for an anti-Ang

I/II antibody could be seen in the entire PDL tissue while bone and dentin

matrices showed no positive reactions (Figs. 2A-2C). Ang I/II protein also

strongly expressed in the cytoplasm of HPLF-2Es as compared with the negative

control (Figs. 2D, 2E), and HPLF-2Ds revealed the same results (data not

shown).

\section{The effects of Ang II on gene expression of HPLFs}

We next wanted to determine whether Ang II could mimic the effects of stretch

loading on gene expressions in HPLFs. Both TGF- $\beta 1$ and ALP mRNA

expressions were up-regulated dose-dependently by the $1 \mathrm{~h}$-stimulus of

recombinant Ang II in HPLF-2E cultures (Fig. 2F). Additionally, HPLF-2Es

treated with recombinant Ang II for $1 \mathrm{~h}$ up-regulated OPG and AGT mRNA

expressions and down-regulated RANKL mRNA expression, similar to that

stimulated by exposure to stretch loading (Fig. 2G). In HPLF-2Ds, Ang II

significantly increased the gene expressions of both TGF- $\beta 1$ and ALP (Fig. $2 \mathrm{H})$. 


\section{Roles of two Ang II receptors in HPLFs exposed to stretch loading}

We examined whether stretch-induced TGF- $\beta 1$ and ALP mRNA expressions were modulated through the Ang II receptor in HPLFs. Both HPLF-2D and -2E cultures exhibited gene expressions of AT1 and AT2 (Fig. 3A). Before exposure to the stretch loading, HPLF-2Es were pre-incubated with candesartan or PD123319. After loading, only PD123319 suppressed up-regulation of gene expressions of both TGF- $\beta 1$ and ALP by the stretch loading (Figs. 3B, 3C). In contrast, candesartan had no effects on the stretch-mediated gene expressions of TGF- $\beta 1$ and ALP. 


\section{DISCUSSION}

Stretch loading caused by occlusion and mastication functionally contributes to the homeostasis of oxytalan fibers in PDL tissue (Tsuruga et al., 2008). However, excess mechanical loading of PDL tissues has been reported to induce osteoclastogenesis / cementoclastogenesis that resorbs bone or root via up-regulated RANKL expression in human PDL cells (Yamaguchi et al., 2006). Human PDL cells regulate osteoclastogenesis by opposing mechanisms, including stimulation by RANKL combined with inhibition by OPG (Kanzaki et al., 2001), and tensile loading that inhibits osteoclastogenesis through OPG induction (Kanzaki et al., 2006). Therefore, in the present study, we recognized the possibility to reduce RANKL expression and to induce OPG expression during stretch loading, and that this mechanism may be necessary for bone metabolism and maintenance of the PDL tissues. Indeed, our present data demonstrated that $8 \%$ stretch loading down-regulated mRNA expression of RANKL and up-regulated that of OPG. Thus, we fixed the elongation rate at $8 \%$ for the necessary magnitude of stretch loading to investigate the associated biological effects.

A recent study showed that mechanical stretch activated AGT mRNA 
expression and caused secretion of Ang II in cardiomyocytes (Yamazaki et al., 1995), and other reports have also demonstrated that Ang II acts as a mediator of the mechanical stretch signaling in cardiomyocytes (Sadoshima et al., 1993; Tamura et al., 1998). These reports support our present results, which showed that $8 \%$ stretch loading up-regulated mRNA expression of AGT in HPLFs. Thus, we hypothesized that RAS, including AGT, may be involved in the signal transduction in HPLFs that have been exposed to stretch loading. In this study, we demonstrated that Ang I/II was localized in PDL tissues, and furthermore, that HPLFs expressed Ang II receptors, AT1 and AT2. Though there are few reports about the role of Ang II in the PDL tissues, these results suggest that Ang II plays a role in maintaining PDL tissues in an autocrine or paracrine manner. Surprisingly, our present data showed that mimicking the stimulus by exposure to $8 \%$ stretch loading, exogenous Ang II significantly up-regulated the expression of AGT, TGF- $\beta 1$, ALP and OPG, and down-regulated that of RANKL. Therefore, we speculate that Ang II is involved in the cellular signaling of stretch loaded-HPLFs.

Finally, we investigated the signaling pathways in stretched HPLFs using specific antagonists of Ang II receptors. Pre-incubation of HPLF cultures with an 
AT2 antagonist, but not an AT1 antagonist, suppressed up-regulation of gene expressions of both TGF- $\beta 1$ and ALP by the stretch loading. However, because there is little information about the AT2 pathway with regard to stretch loading, further studies are necessary to elucidate this mechanism.

TGF- $\beta 1$ is one of the most multifunctional peptides, which is involved in a wide variety of biological processes (Mehta and Attramadal, 2003). Recent studies have revealed that in human PDL cells exposed to orthodontic force, mRNA expression of TGF- $\beta 1$ was augmented in both the compression side and tension side (Garlet et al., 2007). Additionally, in cardiomyocytes, Ang II has been reported to act as a paracrine mediator of stretch-induced TGF- $\beta 1$ mRNA expression (van Wamel JET et al., 2002). These reports support our current data. Other researchers have discussed that TGF- $\beta 1$, up-regulated by mechanical stretch, plays a critical role in the healing and remodeling process of the human anterior cruciate ligament (Kim et al., 2002). Therefore, the percentage of stretch loading utilized in this study may be suitable to further investigate the metabolism of the PDL tissues that are exposed to mechanical stress.

A couple of studies have shown that human PDL cells express some osteoblastic characteristics in vitro (Somerman et al., 1988) and that mechanical 
stimulation, including tensile force, can induce the differentiation of human PDL cells into osteoblast-like cells (Matsuda et al., 1998; Yang et al., 2006).

Short-term stretch loading significantly induced ALP mRNA expression in human PDL cells cultured in three dimensions (Ku et al., 2009). The experimental loading system used in our present report resulted in the up-regulation of ALP expression in HPLFs induced by exposure to stretch loading.

We summarize the current results in Fig. 4. PDL cells expressed Ang I/II, and stretch loading up-regulated gene expression of AGT, which is potentially converted into Ang I/II by RAS, in HPLFs. Subsequently, extracellularly-secreted Ang II may up-regulate mRNA expression of TGF- $\beta 1$ and ALP in an autocrine/paracrine manner via the stimulation of the AT2 signaling pathway in HPLFs. In conclusion, we have obtained evidence that Ang II is involved as a transducer of the stretch loading signals in HPLFs, which consequently induces expression of TGF- $\beta 1$ and ALP. 


\section{ACKNOWLEDGMENTS}

This work was supported by grants-in-aid (projects 19390486, 20791387, 21390510 and 21791942) for scientific research from the Ministry of Education,

Culture, Sports, Science, and Technology, Japan. 


\section{REFERENCES}

Basdra EK, Komposch G (1997). Osteoblast-like properties human periodontal ligament cells: an in vitro analysis. Eur J Orthod 19:615-621.

Jeunemaitre X, Soubrier F, Kotelevtsev YV, Lifton RP, Williams CS, Charru A, Hunt SC, Hopkins PN, Williams RR, Lalouel JM, Corvol P (1992). Molecular basis of human hypertension: role of angiotensinogen. Cell 71:169-180.

Fujii S, Maeda H, Wada N, Kano Y, Akamine A (2006). Establishment and characterizing human periodontal ligament fibroblasts immortalized by SV40T-antigen and hTERT gene transfer. Cell Tissue Res 324: 117-125.

Garlet TP, Coelho U, Silva JS, Garlet GP (2007). Cytokine expression pattern in compression and tension sides of periodontal ligament during orthodontic tooth movement in humans. Eur J Oral Sci 115:355-362.

Inagami T, Iwai N, Sasaki K, Yamamo Y, Bardhan S, Chaki S, Guo DF, Furuta H (1992). Cloning, expression and regulation of angiotensin II receptors. J Hypertens 10:713-716.

Izu Y, Mizoguchi F, Kawamata A, Hayata T, Nakamoto T, Nakashima K, Inagami T, Ezura Y, Noda M (2008). Angiotensin II type 2 receptor blockade increases bone mass. J Biol Chem 284:4857-4864. 
Kanzaki H, Chiba M, Shimizu Y, Mitani H (2001). Dual regulation of osteoclast differentiation by periodontal ligament cells through RANKL stimulation and OPG inhibition. J Dent Res 80:887-891.

Kanzaki H, Chiba M, Sato A, Miyagawa A, Arai K, Nukatsuka S, Mitani H (2006). Cyclical tensile foce on periodontal ligament cells inhibits osteoclastogenesis through OPG inhibition. J Dent Res 85:457-462.

Kim SG, Akaike T, Sasagaw T, Atomi Y, Kurosawa H (2002). Gene expression of type I and type III collagen by mechanical stretch in anterior cruciate ligament cells. Cell Struct Funct 27:139-144.

Ku SJ, Chang YI, Chae CH, Kim SG, Park Yw, Jung YK, Choi JY (2009). Static tensional forces increase osteogenic gene expression in three-dimensional periodontal ligament cell culture. BMB reports 42:427-432.

Maeda H, Wada N, Fujii S, Akamine A (2005). Fibroblastic cells from human periapical granulation tissue preferentially form calcified matrices in decalcified boiled rat bone. Cell Tissue Res 320:135-140.

Matsuda N, Morita N, Matsuda K, Watanabe M (1998). Proliferation and differentiation of human osteoblastic cells associated with differential activation of MAP kinases in response to epidermal growth factor, hypoxia, 
and mechanical stress in vivo. Biophys Res Commun 249:350-354.

Mehta JL, Attramadal H (2003). The TGF $\beta$ superfamily in cardiovascular biology. Cardiovasc Res 74:181-183.

Sadoshima J, Xu Y, Slayter HS, Izumo S (1993). Autocrine release of Angiotensin II mediates stretch-induced hypertrophy of cardiac myocytes in vitro. Cell 75:977-984.

Senbonmatsu T, Saito T., Landon E, Watanabe O, Price EJ, Roberts R, Imboden H, Fitzgerald T, Gaffney F, Inagami T (2003). A novel angiotensin II type 2 receptor signaling pathway: possible role in cardiac hypertrophy. EMBO J 22:6471-6482.

Shi L, Kodama Y, Atsumi Y, Honma S, Wakisaka S (2005). Requirement of occlusal force for maintenance of the terminal morphology of the periodontal Ruffini endings. Arch Histol Cytol 68:289-299.

Somerman MJ, Archer SY, Imm GR, Foster RA (1988). A comparative study of human periodontal ligament cells and gingival fibroblasts in vitro. J Dent Res 67: 66-70.

Tamura K, Umeura S, Nyui N, Hibi K, Ishigami T, Kihara M, Toya Y, Ishii M (1998). Activation of angiotensinogen gene in cardiac myocytes by 
angiotensin II and mechanical stretch. Am J Physiol 275:R1-9.

Tomikiyo A, Maeda H, Fujii S, Wada N, Shima K, Akamine A (2008).

Development of a multipotent clonal human periodontal ligament cell line.

Differentiation 76:337-347.

Tsuruga E, Nakashima K, Ishikawa H, Yajima T, Sawa Y (2008). Stretching modulates oxytalan fibers in human periodontal ligament cells. J Periodont Res 10:1111.

Udagawa N (2002). Mechanisms involved in bone resorption. Biogerontology 3:79-83.

van Wamel JET, Ruwhof C, van der Valk-Kokshoorn LJM, Schrier PI, van der Laarse A (2002). Stretch-induced paracrine hypertrophic stimuli increase TGF- $\beta 1$ expression in cardiomyocytes. Mol Cell Biochem 236:147-153.

Wada N, Maeda H, Tanabe K, Tsuda E, Yano K, Nakamuta H, Akamine A (2001). Periodontal ligament cells secrete the factor that inhibits osteoclastic differentiation and function: the factor is osteoprotegerin / osteoclastogenesis inhibitory factor. J Periodontal Res 36:56-63.

Wada N, Maeda H, Yoshimine Y, Akamine A (2004). Lipopolysaccharide stimulates expression of osteoprotegerin and receptor activator of NF-kappa 
B ligand in periodontal ligament fibroblasts through the induction of interleukin-1 beta and tumor necrosis factor-alpha. Bone 35:629-635.

Yamaguchi M, Aihara N, Kojima T, Kasai K (2006). RANKL increase in compressed periodontal ligament cells from root resorption. J Dent Res 85:751-756.

Yamaguchi N, Chiba M, Mitani H (2002). The induction of c-fos mRNA expression by mechanical stress in human periodontal ligament cells. Arch Oral Biol 47:465-471.

Yamazaki T, Komuro I, Kudoh S, Zou Y, Shiojima I, Mizuno T, Takano H, Hiroi Y, Ueki K, Tobe K, Kadowaki T, Nagai R, Yazaki Y (1995). Angiotensin II partly mediates mechanical stress-induced cardiac hypertrophy. Circ Res $77: 258-265$.

Yang YQ, Li XT, Rabie AB, Fu MK, Zhang D (2006). Human periodontal ligament cells express osteoblastic phenotypes under intermittent force loading in vitro. Front Biosci 11:776-781. 


\section{Figure Legends}

Figure 1.

The effects of stretch loading on gene expression of RANKL (A) and OPG (B) in HPLFs. HPLF-2E cultures were exposed to stretch loading of 0,8 and $12 \%$ elongation for $1 \mathrm{~h}$, and the gene expressions of RANKL and OPG in the cell cultures were assessed by semi-quantitative RT-PCR. The stretch loading of $8 \%$ down-regulated mRNA expression of RANKL, as compared with $0 \%$, while the stretch loading of $12 \%$ up-regulated the expression. The stretch loading of both $8 \%$ and $12 \%$ up-regulated mRNA expression of OPG. The gene expressions of TGF- $\beta 1$, ALP and AGT in HPLF-2Ds (C) and HPLF-2Es (D) exposed to the stretch loading of $8 \%$ were examined by quantitative RT-PCR. The results are shown as mean \pm SD from three different experiments. ${ }^{* *} p<0.02$.

Figure 2.

Localization of Ang II in rat PDL tissue and HPLFs (A-E). Ang II immunoreactivity was detected in PDL tissues. Dentin, bone matrices and pulp tissues showed negative reactions (A). A magnified view of the rectangle area in $(A)$ is shown in (B). Both PDL cells and extra-cellular-matrix in PDL tissues showed strongly 
positive reactions ( $D$, dentin; $P D L$, periodontal ligament; $B$, bone) (B). Control staining with serial sections showed negative reactions (C). Ang II immunoreactivity could be seen in the cytoplasm of HPLF-2Es (D). Control staining of HPLF-2Es showed no positive reactions (E). Bars, $100 \mu \mathrm{m}$. Gene expression in HPLF-2Es stimulated with Ang II analyzed by quantitative RT-PCR are shown $(\mathrm{F}-\mathrm{H})$. The expressions of TGF- $\beta 1$ and ALP mRNA were up-regulated dose-dependently by a $1 \mathrm{~h}$-stimulus of recombinant Ang II in HPLF-2Es (F). OPG and AGT mRNA expressions were up-regulated by the $1 \mathrm{~h}$-stimulus of recombinant Ang II in HPLF-2Es, while RANKL mRNA expression was down-regulated (G). TGF- $\beta 1$ and ALP mRNA expressions were also up-regulated by the $1 \mathrm{~h}$-stimulus of recombinant Ang II in HPLF-2Ds $(\mathrm{H})$. The values were compiled as mean $\pm S D$ from three different experiments. ${ }^{* *} p<0.02$, ${ }^{*} p<0.05$

Figure 3.

Gene expression of Ang II receptors in HPLFs and the effects of Ang II receptor antagonists on the mRNA expressions of stretch-induced TGF- $\beta 1$ and ALP. The expressions of AT1 and AT2 mRNA both in HPLF-2Ds and in HPLF-2Es were 
examined by semi-quantitative RT-PCR (A). mRNA expressions of stretch-induced TGF- $\beta 1$ (B) and ALP (C) as they were affected by Ang II receptor antagonists and stretch loading. HPLF-2Es were incubated with or without an AT1 antagonist, candesartan (10 ng/ml), or an AT2 antagonist, PD123319 (100nM), for 30 min before exposure to $1 \mathrm{~h}$-stretch loading. The values of quantitative RT-PCR data are reported as mean \pm SD from three different experiments. ${ }^{* *} p<0.02,{ }^{*} p<0.05$.

Figure 4.

Proposed Ang II-mediated signaling in HPLFs exposed to stretch loading.

HPLFs exposed to a stretch loading of $8 \%$ up-regulated AGT expression and secreted Ang II. Ang II up-regulated TGF- $\beta 1$ and ALP expressions in HPLFs via AT2 only, but not AT1, in an autocrine or paracrine manner. 
Figure.1
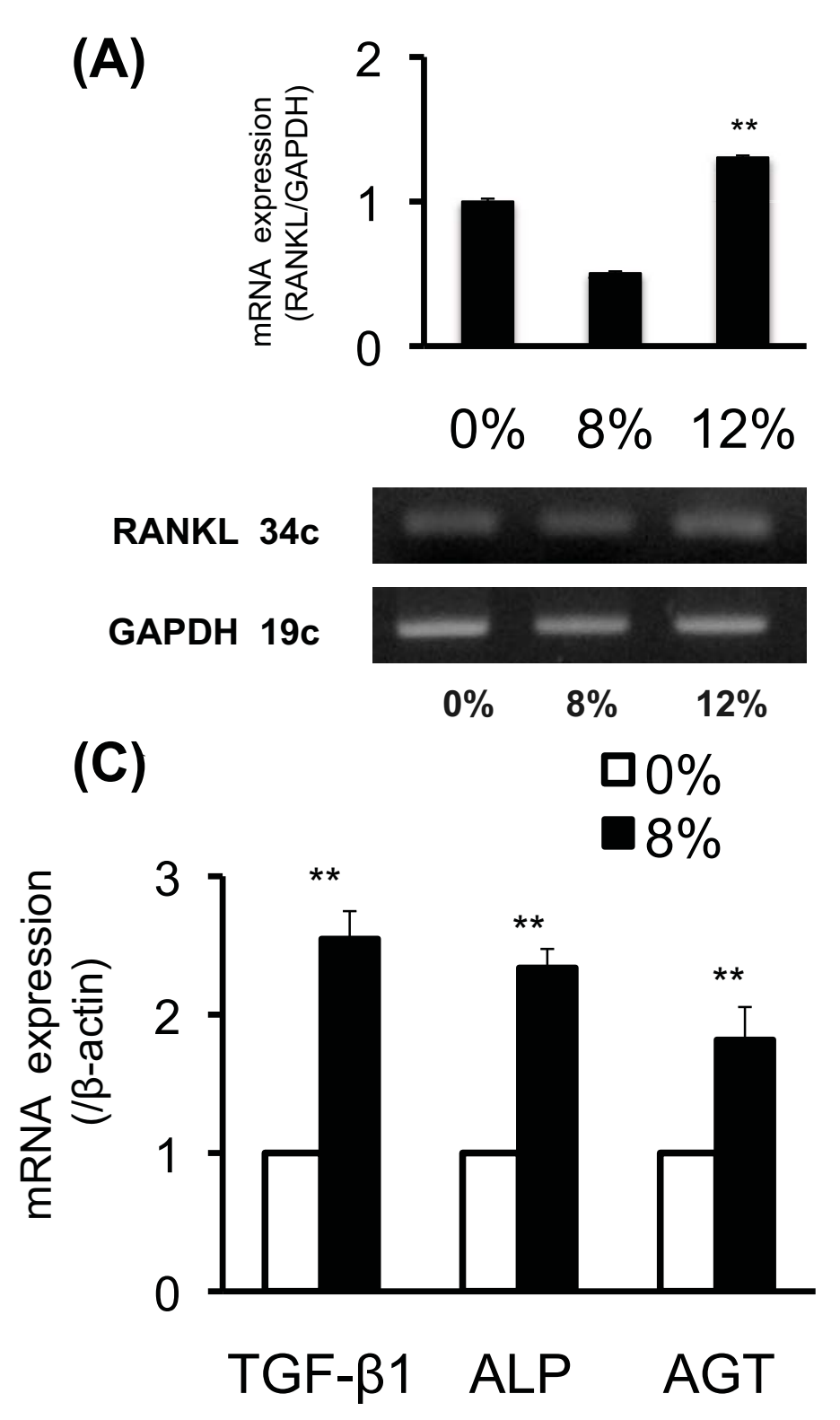
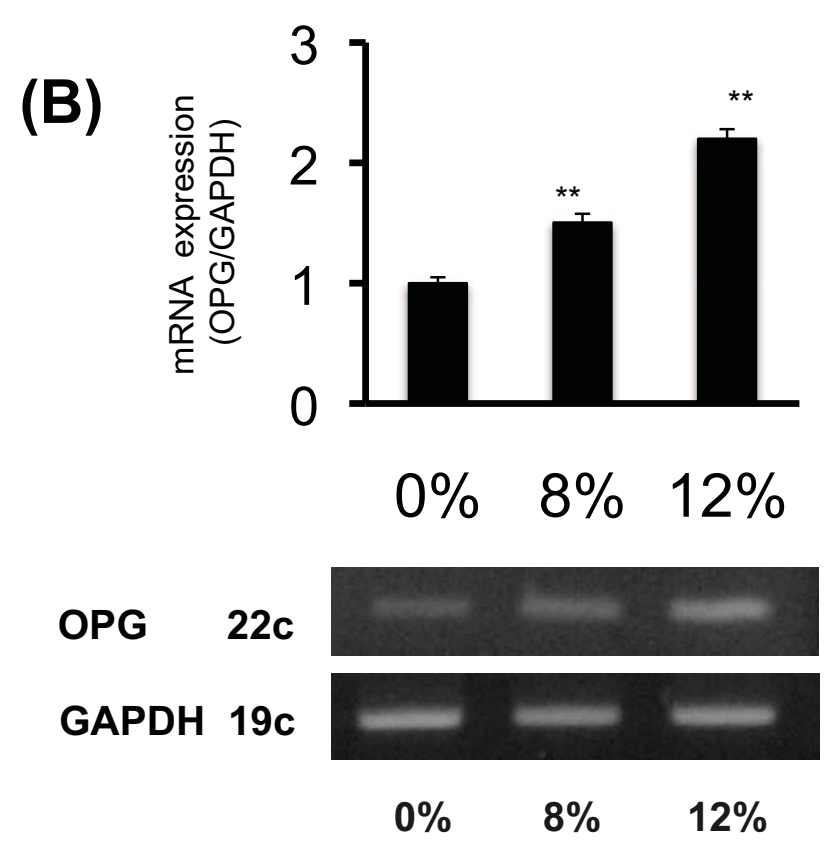

(D)

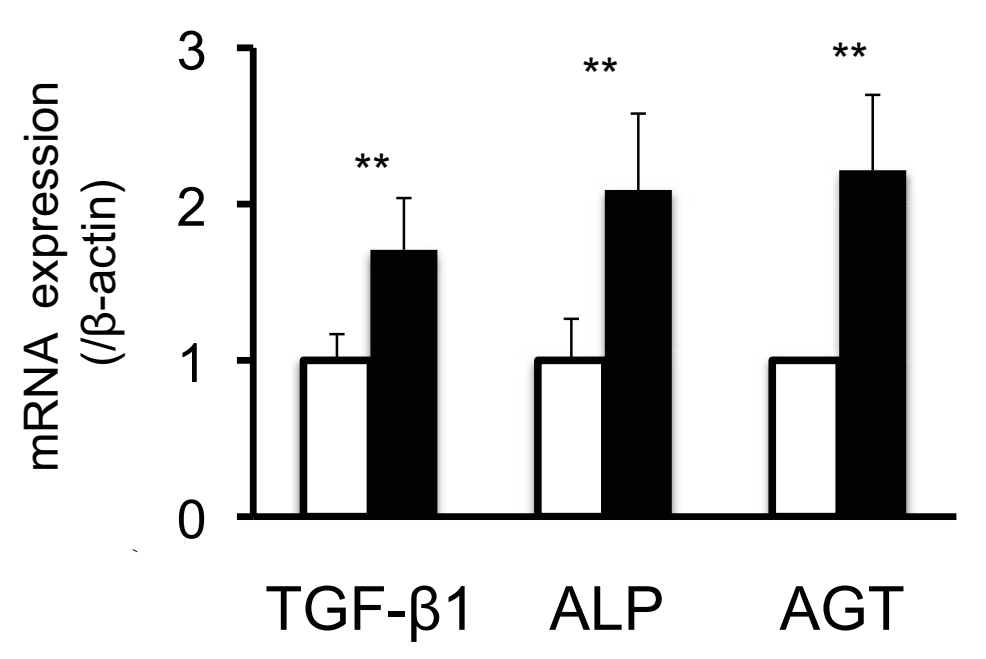




\section{Figure. 2}

(A)

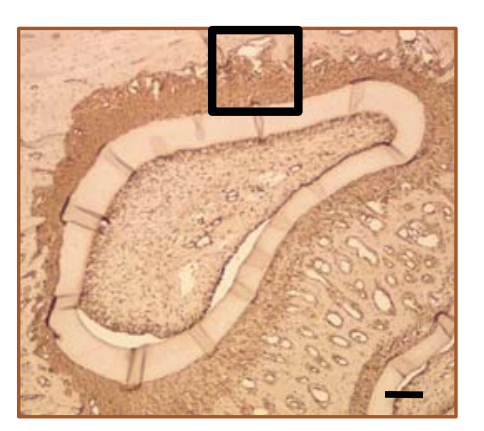

(D)

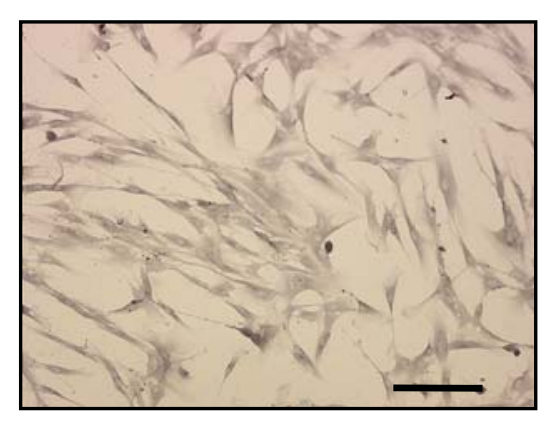

(F)

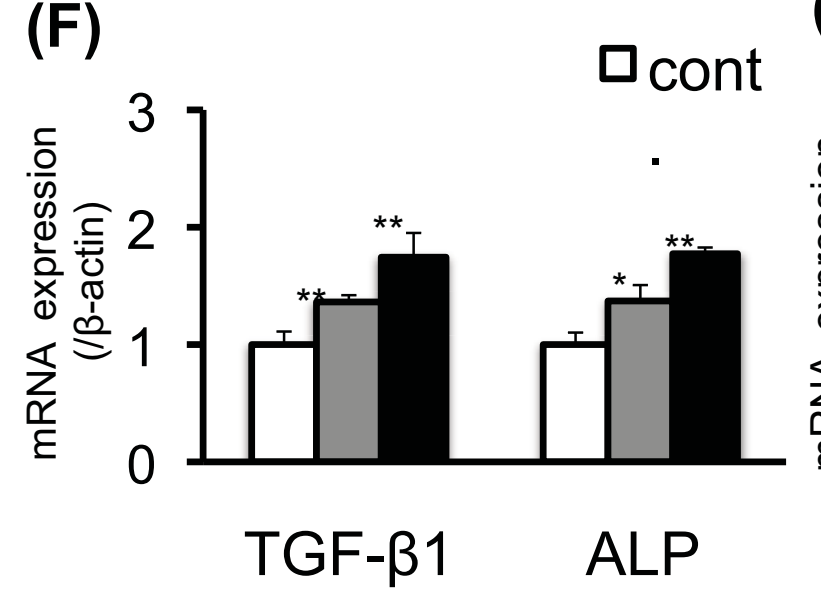

(B)

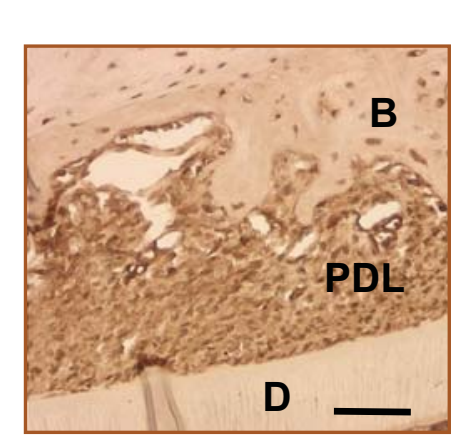

(E)

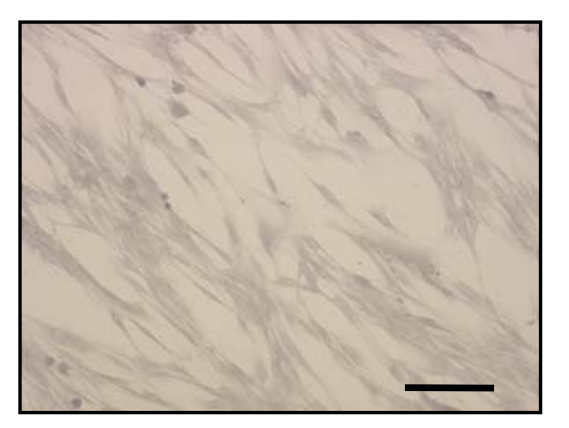

(G)
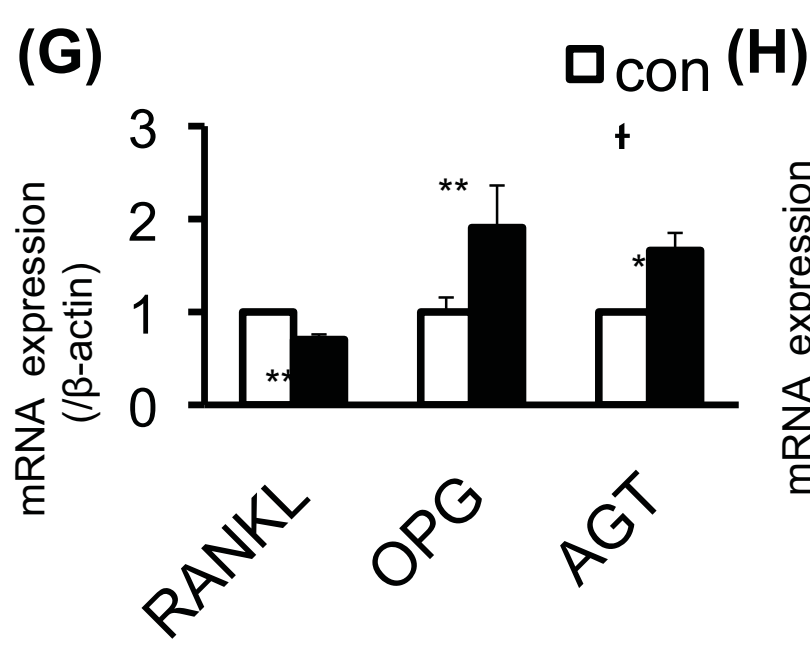

(C)

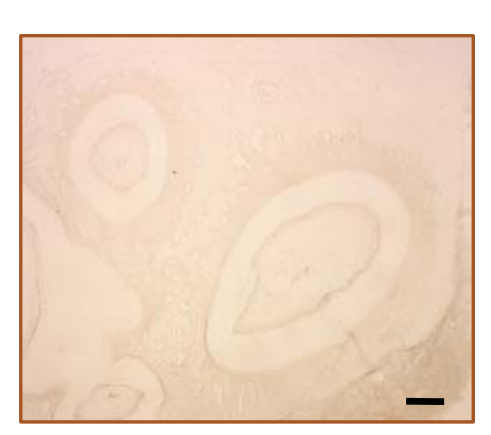


Figure.3

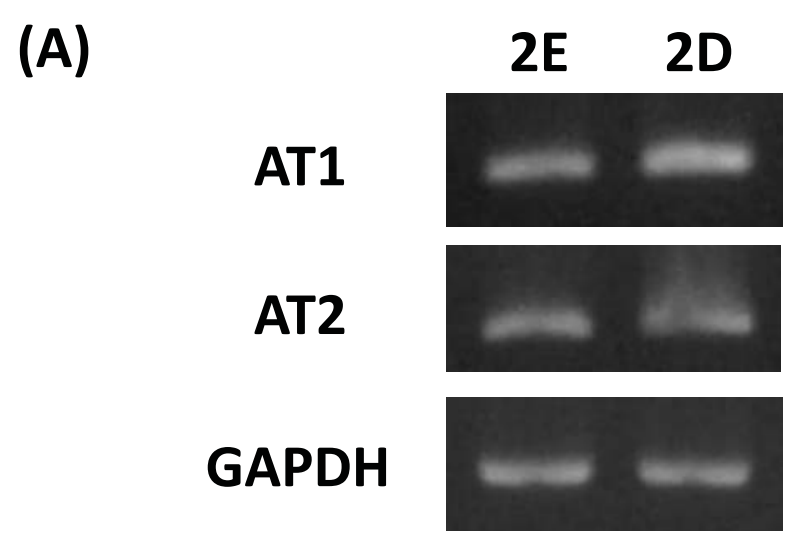

(B)

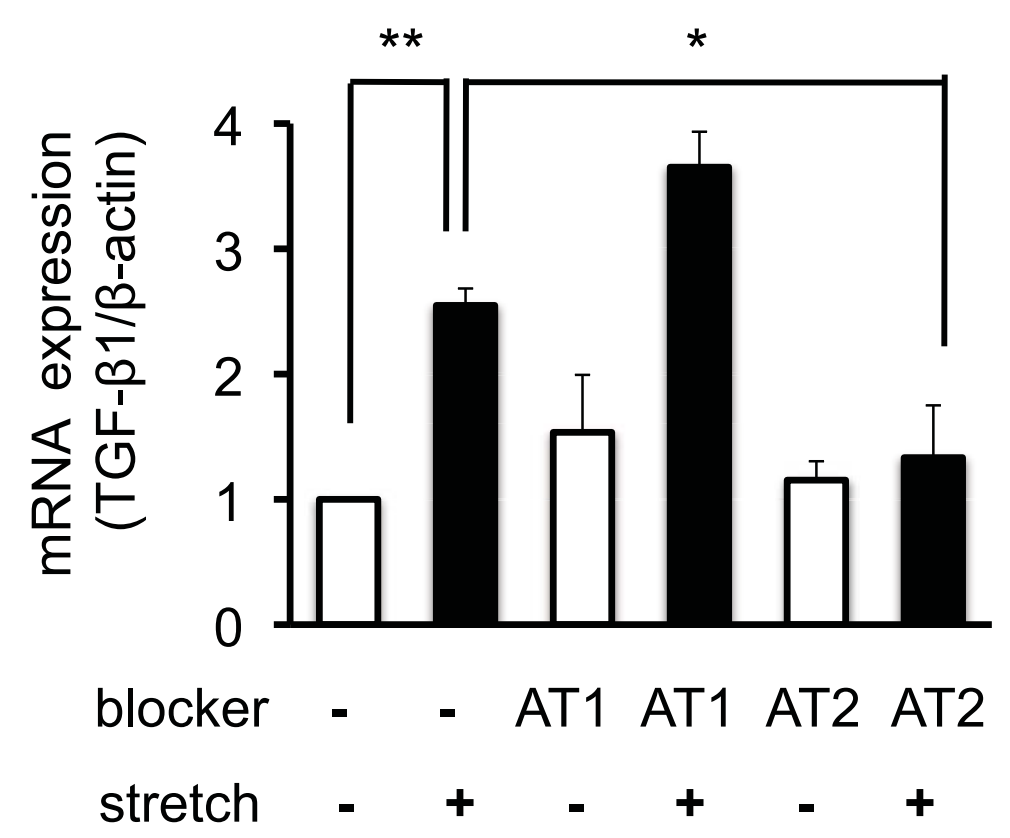

(C)

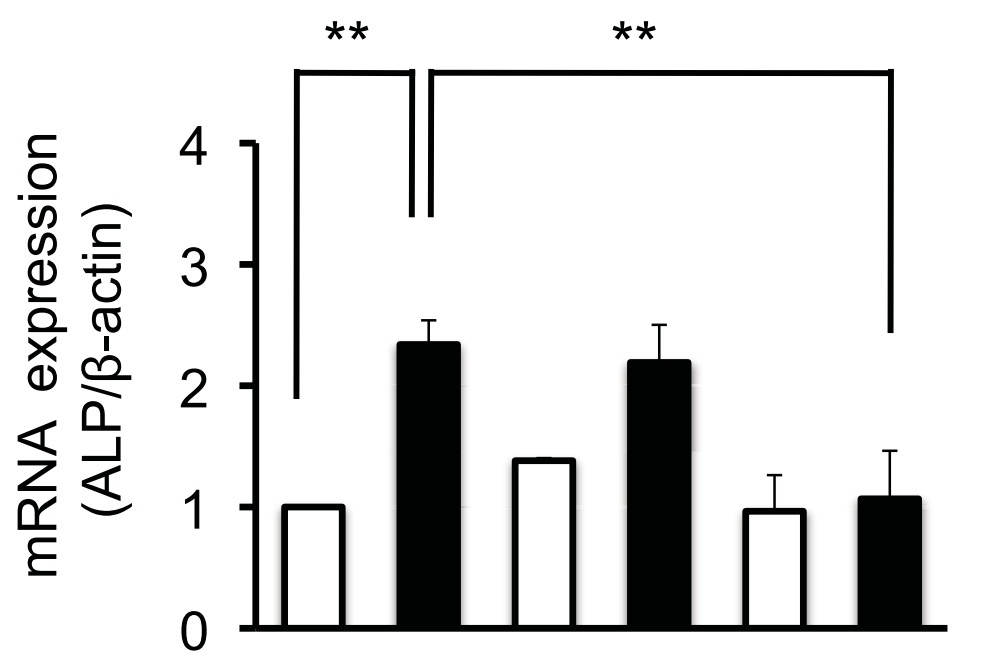

blocker - - AT1 AT1 AT2 AT2

stretch - + - + - + 
Figure.4

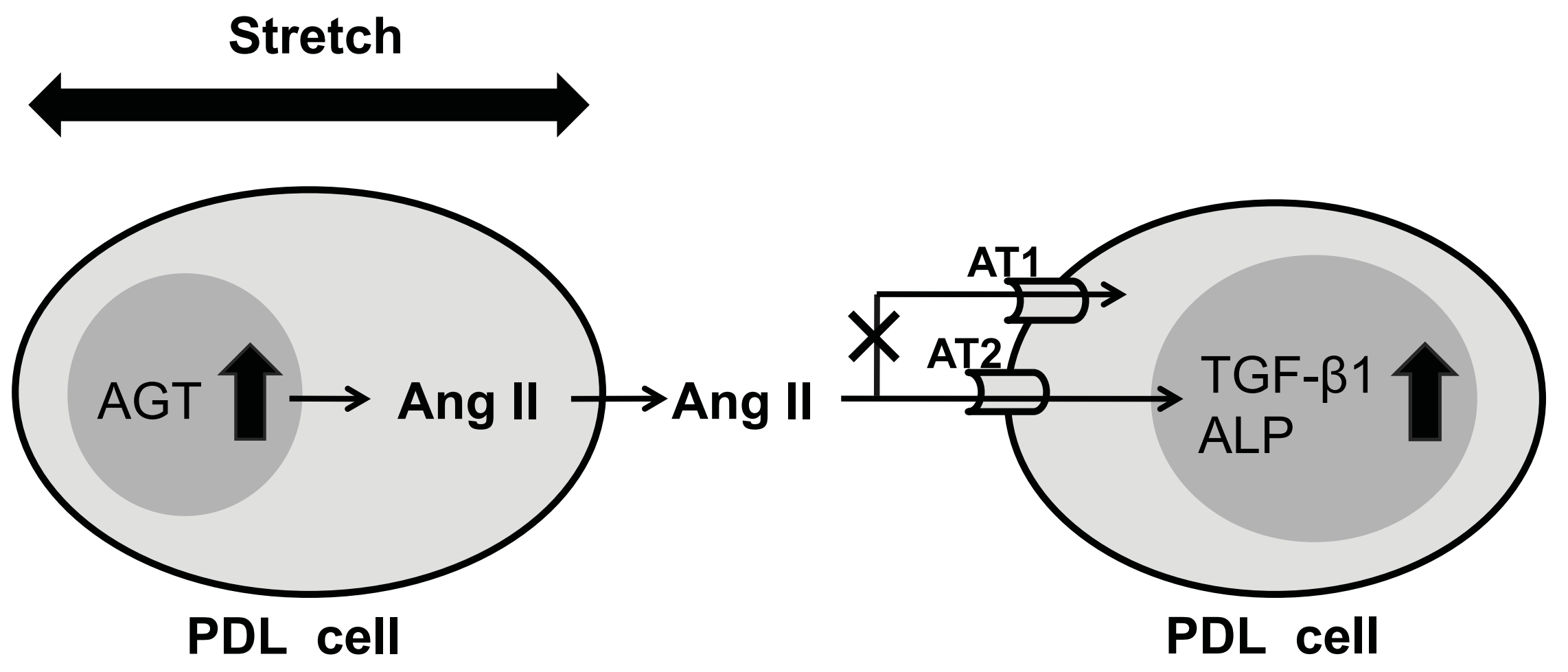

